\title{
Correction to: Early Life Stress and Childhood Aggression: Mediating and Moderating Effects of Child Callousness and Stress Reactivity
}

\author{
Dominika A. Winiarski $^{1}$ [ $\cdot$ Melissa L. Engel ${ }^{2} \cdot$ Niranjan S. Karnik $^{1} \cdot$ Patricia A. Brennan $^{3}$
}

Published online: 24 February 2018

(c) The Author(s) 2018. This article is an open access publication

\section{Correction to: Child Psychiatry \& Human Development https://doi.org/10.1007/s10578-018-0785-9}

The article "Early Life Stress and Childhood Aggression: Mediating and Moderating Effects of Child Callousness and Stress Reactivity", written by Dominika A. Winiarski, Melissa L. Engel, Niranjan S. Karnik and Patricia A. Brennan, was originally published electronically on the publisher's internet portal (https://link.springer.com/artic le/10.1007/s10578-018-0785-9) on 13 February 2018 without open access.

With the author(s)' decision to opt for Open Choice the copyright of the article changed on 18 February 2018 to $($ ) The Author(s) 2018 and the article is forthwith distributed under the terms of the Creative Commons Attribution 4.0
International License (http://creativecommons.org/licenses/ by/4.0/), which permits use, duplication, adaptation, distribution and reproduction in any medium or format, as long as you give appropriate credit to the original author(s) and the source, provide a link to the Creative Commons license and indicate if changes were made.

The Original article has been corrected.

Open Access This article is distributed under the terms of the Creative Commons Attribution 4.0 International License (http://creativeco mmons.org/licenses/by/4.0/), which permits unrestricted use, distribution, and reproduction in any medium, provided you give appropriate credit to the original author(s) and the source, provide a link to the Creative Commons license, and indicate if changes were made.
The original article can be found online at https://doi.org/10.1007/ s10578-018-0785-9.

Dominika A. Winiarski

Dominika_A_Winiarski@rush.edu

1 Department of Psychiatry, Rush University Medical Center, 1700 W. Van Buren St., Suite 5827A, Chicago, IL 60612, USA

2 Institute of Child Development, University of Minnesota, Minneapolis, MN, USA

3 Department of Psychology, Emory University, Atlanta, GA, USA 